\title{
KITAB AL-SANĪ AL-MAṬ̂̄LIB: Interkoneksi Nahwu dan Tasawuf
}

\author{
Zakiyah \\ Balitbang Agama Semarang \\ e-mail: zaki_smart@yahoo.com
}

\begin{abstract}
This paper reviews a book entitled al-Sanī al-Mațālib written by Kiai Nur Iman Mlangi Yogyakarta. This book is written in Arabic containing an interconnection between Arabic grammar and mysticism. This book is very interesting due to the fact that those two knowledges have its own rules. In addition, there is only small number of authors who had written with the same model, to name one of them is Shaikh Abdul Qadir bin Ahmad al-Kuhany with his work entitled Manniyat al-Fäqir alMunjarid wa Sayrat al-Murìd al-Mutafarrid". The book al-Sanī al-Mațālib was predicted written in the late 18s Century or the beginning of 19s century, it is based on the period of Kiai Nur Iman's life in which around the mid of 18s century. The grammatical rule of Arabic in this book was explained theosophically, it is started with the explanation of tauhid (oneness) as the basic learning for Muslim, followed by the meaning of each Arabic rule in mystical aspect.

***

Tulisan ini mereview buku yang berjudul al-Sanī al-Mațālib yang ditulis oleh Kiai Nur Iman Mlangi Yogyakarta. Buku ini ditulis dalam bahasa Arab yang mengandung interkoneksi antara ilmu Nahwu (tata bahasa Arab) dengan mistisisme. Buku ini sangat menarik karena kenyataan bahwa kedua pengetahuan tersebut memiliki aturan sendiri-sendiri. Selain itu, sangat sedikit penulis yang menulis dengan gaya seperti itu. Salah satunya adalah Syaikh Abdul Qadir bin Ahmad alKuhany dengan karyanya yang berjudul Manniyat al-Fāqir al-Munjarid wa Sayrat al-Murīd al-Mutafarrid. Buku al-Saniy al-Muthalib diduga telah ditulis pada akhir abad ke-18 atau awal abad ke-19, menurut periode kehidupan Kiai Nur Iman yaitu sekitar pertengahan abad ke-18. Aturan Nahwu dalam buku ini dijelaskan secara teosofi yang dimulai dengan penjelasan mengenai tauhid (keesaan Tuhan) sebagai kajian dasar bagi orang Islam, yang diikuti dengan makna dari masingmasing aturan bahasa Arab dalam aspek mistiknya.
\end{abstract}

Keywords: al-Sanī al-Mațālib, Nahwu, tasawuf, Kiai Nur Iman 


\section{A. Pendahuluan}

Kitab al-San̄ al-Mațālib adalah karya Kiai Nur Iman yang membahas masalah ilmu Nahwu (gramatika bahasa Arab) dengan penjelasan tasawuf. Kaidah-kaidah gramatika bahasa Arab dijelaskan makna simboliknya. Membaca kitab ini, seseorang harus telah mengetahui terlebih dahulu kitab-kitab Nahwu yang ada, dan tentu saja ilmu tasawuf. Sepertinya kitab ini ditujukan bagi pembaca tingkat atas. Meskipun tidak diketahui runtutan waktu penulisan dari kitab-kitab karya Kiai Nur Iman, sepertinya kitab al-Sanī al-Mațālib merupakan kitab lanjutan dari dua kitab yang lainnya yaitu al-Risālah dan Taqwìm.

Pembahasan yang dilakukan oleh Kiai Nur Iman di dalam kitab al-San̄̄ al-Matālib ini menarik dan penting untuk diteliti mengingat hal ini tidak biasa dilakukan oleh ulama-ulama penulis kitab. Di dalam kitab ini terdapat intekoneksi antara dua disiplin ilmu besar yang keduanya sama-sama telah mapan, dan tentu saja ada bidang ilmu lain juga yang turut serta di dalam pembahasan seperti ilmu tauhid. Kajian interdisipliner ini menjadi terasa luar biasa tatkala merujuk pada masa hidup Kiai Nur Iman, yakni sekitar pertengahan abad ke-18an sampai awal abad ke-19an.

Kitab al-Sanī al-Mațālib ditulis dengan menggunakan aksara dan bahasa Arab, dan merupakan karya orisinal dari Kiai Nur Iman. Meskipun kaidahkaidah bahasa Arab yang digunakan adalah kaidah baku yang ada di dalam ilmu Nahwu, namun penjelasan-penjelasannya merupakan penjelasan yang diberikan oleh Kiai Nur Iman. Karya ini berbeda dengan karya sejenis yang telah ada, misalnya kitab Manniyat al-Faqīr al-Munjarid wa Sayrat al-Murid alMutafarrid karya Syaikh Abdul Qadir bin Ahmad al-Kuhany yang telah diterjemahkan dengan judul Rahasia Ilahi di Balik Gramatika Bahasa Qur'aniy: Sebuah Telaah Sufistik atas Kitab al-Ajurumiy.

Berdasarkan pemikiran di atas, maka penting dilakukan penelitian terhadap kitab al-Sanī al-Mațālib. Selain itu Kiai Nur Iman merupakan ulama yang telah membuka desa Mlangi Yogyakarta dan menjadikannya tempat bersemainya Islam di wilayah tersebut dan sekitarnya. Lebih lanjut, keberadaannya dengan karyanya tersebut merupakan kekayaan intelektual bagi bangsa Indonesia, dan butir-butir pemikirannya masih perlu terus untuk dikaji. Dalam kesempatan ini, terdapat tiga hal yang dilihat dan dipaparkan yakni; bagaimana profil Kiai Nur Iman, bagaimana kondisi kitab al-Sanī al- 
Mațālib dan apa interkoneksi antara Nahwu dan tasawuf dalam kitab al-Sanī al-Mațālib.

\section{B. Kiai Nur Iman: Ulama dari Keraton Kartasura}

Raden Mas Sandiyo, atau kelak kemudian hari dikenal dengan nama Kiai Nur Iman, adalah salah satu putra dari Amangkurat Jawa penguasa kerajaan Mataram di Kartasura. Menurut tradisi lisan yang berkembang di desa Mlangi Yogyakarta dikatakan; Ia dilahirkan di Gedangan Surabaya, di pesantren tempat Amangkurat Jawa belajar agama sewaktu muda. Ia lahir dari istri pertamanya yang bernama Ratna Susilowati (putri dari Adipati Wiranegara/ Untung Surapati penguasa Pasuruan). Dalam hal ini, Raden Mas Sandiyo adalah anak pertama dari Amangkurat Jawa. ${ }^{1}$

Sementara itu, di dalam buku Keraton Ngayogyakarta Hadiningrat, Raden Mas Sandiyo adalah putra Amangkurat Jawa dari istrinya yang bernama Raden Ayu Herawati dari Pemalang (putri dari Adipati Sindupraya). Disebutkan di dalam buku tersebut, Raden Mas Sandiyo merupakan anak kelima dari 42 bersaudara dengan ibu yang berbeda-beda.

Tradisi tutur menyebutkan nama "Sandiyo" adalah pemberian dari ayahnya, sedangkan "Nur Iman" merupakan nama pemberian dari Kiai Abdullah Muchsin. Tahun kelahiran dari Raden Mas Sandiyo tidak diketahui dengan persis, namun apabila kita merujuk pada masa Amangkurat Jawa memegang tahta Mataram (1719-1727), maka dapat dimungkinkan ia lahir sekitar tahun 1719an atau 1720an. Hal ini dapat dirunut dari ayahnya yang meninggalkan Gedangan menuju Kartasura, ketika itu istrinya sedang mengandung Raden Mas Sandiyo. Sesampainya di keraton Kartasura, tidak lama kemudian Raden Mas Suryo Putro dinobatkan menjadi raja Mataram dan bergelar Amangkurat IV/Amangkurat Jawa.

Masa kecil hingga menjelang dewasa, Nur Iman menghabiskannya di pesantren Gedangan. Di tempat inilah ia belajar berbagai ilmu agama seperti ilmu tauhid, fiqh, tasawuf, tata bahasa Arab dan lainnya. Ia terus tumbuh

\footnotetext{
${ }^{1}$ Data pada sub bab ini disarikan dari; Hidayat, Taufik dan Adib, Ma'wal, Sekilas Sejarah Mbah Kiai Nur Iman (BPH Sandiyo) dan Berdirinya Masjid Jami' Mlangi, (Yogyakarta: Pelaksana Penyelenggara Khaul Mbah Kiai Nur Iman Mlangi, 2006). Dwiyanto, Djoko. Keraton Yogyakarta; Sejarah, Nasionalisme dan Teladan Perjuangan, (Yogyakarta: Paradigma Indonesia, 2006). Wawancara dengan para tokoh masyarakat Mlangi Yogyakarta.
} 
menjadi anak yang baik dan shalih yang menguasai baik ilmu syariat maupun hakikat.

Dikisahkan, Nur Iman diminta pulang ke Kartasura ketika ayahnya sakit keras. Amangkurat Jawa, ayah dari Nur Iman, sakit keras dan akan ada suksesi kepemimpinan di Kartasura. Pada saat itu, tersebutlah ada seorang nujum yang berbicara kepada Amangkurat Jawa "paduka punya seorang putra/anak laki-laki". Kemudian, Amangkurat Jawa teringat bahwa ketika ia berada di Surabaya ia pernah menikah. Selanjutnya, ia segera mendelegasikan seseorang untuk menjemput anaknya.

Nur Iman/Sandiyo sudah besar ketika dijemput oleh utusan keraton Kartasura. Ia diminta pulang dan ia-pun bersedia pulang ke Kartasura. Namun, Nur Iman tidak mau bersama dengan utusan raja saat melakukan perjalanan ke Kartasura. Ia lebih memilih untuk ditemani dengan dua orang kawannya yang bernama Sanusi dan Tanwisani. Mereka bertiga siap berangkat menuju Kartasura setelah berpamitan dengan gurunya yaitu Kiai Abdullah Muchsin.

Kiai Abdullah Muchsin berpesan kepada Nur Iman untuk selalu mengingat dan menjaga visi dan misinya sebagai seorang kiai, yakni menyampaikan amar ma'rūf nahi munkar di mana dan kapan saja ia berada. Pesan ini dibuktikan oleh mereka bertiga, disetiap tempat yang mereka lalui mereka selalu menyampaikan ajaran-ajaran Islam. Dari satu kampung ke kampung lainnya dan dari satu desa ke desa lainnya, Nur Iman senantiasa berdakwah dan mampu mendirikan tempat untuk belajar agama Islam.

Perjalanan yang dilakukan oleh Nur Iman dan kawannya memakan waktu hingga beberapa tahun sebelum akhirnya tiba di Keraton Kartasura. Sesampainya di Kartosuro, ia bertemu dengan ayah dan saudara-saudaranya dan mendapat gelar "Bendoro Pangeran Hangabehi (BPH)". Ketika itu Amangkurat Jawa berkata: "Kamu itu adalah putraku, tinggallah di keraton." Akan tetapi, Nur Iman tidak bersedia bertempat tinggal di keraton, karena ia lebih senang tinggal di luar keraton.

Nur Iman diberi hadiah keris sebagai tanda bahwa ia adalah putra dari Amangkurat Jawa. Keris yang sama juga diberikan kepada putranya yang lain, yakni kepada Pangeran Mangkubumi (HB I) dan Pangeran Arya Mangkunegara. Selain itu, Nur Iman juga diberi hadiah tanah oleh ayahnya saat memutuskan untuk keluar dari keraton Kartasura. Di antara alasan yang men- 
dorong Nur Iman keluar dari keraton adalah situasi keraton saat itu yang kurang kondusif, terdapat beberapa perselisihan yang melibatkan anggota keluarga kerajaan dan campur tangan Kompeni (Belanda), serta diperparah dengan adanya pertempuran antara orang-orang Tionghoa dengan Belanda yang terkenal dengan istilah "geger pecinan" yang kemudian merangsek masuk menyerang Kartasura. Nur Iman lebih memilih tinggal di tengah masyarakat untuk berdakwah.

Bersama kedua sahabatnya Sanusi dan Tanwisani, Nur Iman melakukan perjalanan ke arah Barat. Perjalanan ini dimaksudkan untuk menyebarkan ajaran Islam ke tempat-tempat yang mereka singgahi, dan sampailah mereka bertiga di daerah Gegulu (sekarang masuk wilayah Kulon Progo Yogyakarta). Di tempat baru ini mereka disambut dengan baik oleh penguasa desa bernama Demang Hadi Wongso. Setelah yakin bahwa Nur Iman adalah seorang kiai besar maka Demang Hadi Wongso beserta keluarganya masuk agama Islam dan memohon kepada Kiai Nur Iman untuk menikah dengan putrinya yang bernama Mursalah. Tidak lama kemudian, Kiai Nur Iman menikah dengan Mursalah. Sementara itu, Sanusi dinikahkan dengan Maemunah, dan Tanwisani dengan Romlah.

Setelah ayah mertuanya "Demang Hadi Wongso" wafat, Kiai Nur Iman beserta keluarganya melakukan perjalanan kembali ke arah utara. Sampailah mereka di sebuah desa bernama Kerisan. Di tempat ini, kiai Nur Iman melakukan amar ma'rüf nahi munkar yakni mengajarkan ajaran-ajaran agama Islam kepada masyarakat. Diceritakan, ketika di desa inilah ia dicari oleh utusan dari Hamengkubuwono I.

Dari cerita serba-serbi yang beredar di masyarakat Mlangi Yogyakarta dikatakan; Pangeran Mangkubumi (HB I) pada saat hendak menduduki singgasana, ia bermaksud meminta restu dari kakaknya terlebih dahulu. Kemudian, HB I mencarinya dengan mengirim utusan. HB I pernah diperingatkan oleh ayahandanya apabila akan mencari saudaranya maka ia harus mencari seseorang yang mempunyai keris yang sama dengannya, karena ayahnya (Amangkurat Jawa) telah memberikan keris pada masingmasing putranya.

HB I mengumunkan tentang pencarian terhadap Nur Iman. Ia juga mencari Nur Iman, yakni seseorang yang mempunyai keris yang sama dengan HB I. Nur Iman di temukan di sebuah desa, maka desa tersebut terkenal dengan 
sebutan dusun "Kerisan," karena telah ditemukan seseorang yang mempunyai keris.

Nur Iman kemudian diminta untuk hadir ke keraton Yogyakarta. Pada saat itu terjadi dialog:

HB I berkata, "Nyuwun ngapunten Kangmas, Panjenengan punika leres piyantun Kartasura (maaf saudaraku, apakah benar anda ini dari Kartasura)?"

Kiai Nur Iman, "Inggih leres (iya benar)."

HB I bertanya kembali; "Panjenengan punika punapa leres kagungan keris (apakah benar anda mempunyai keris)?"

Kiai Nur Iman menjawab, "Inggih leres (iya benar)."

Kemudian HB I berkata, "Kawula nyuwun pangestu, kawula bade lenggah wonten dampar kencana (saya minta restu, saya akan menduduki singgasana keraton)."

Kiai Nur Iman berujar. "Monggo (silakan)."

Karena pada dasarnya Kiai Nur Iman adalah seorang sufi yang tidak suka kepada hal-hal terkait dunia, ia menjawab, "Enggih kawula donga'aken, (iya saya doakan)," akhirnya jalan yang bagus ditempuh, antara dua saudara saling mendukung, tidak saling berebut warisan. Kemudian, HB I duduk di singgasana dan memegang tampuk kekuasaan keraton Yogyakarta.

Setelah itu terjadi dialog antara keduanya:

HB I bertanya kepada kakaknya, "Kangmas bade tindak pundi (kakak mau pergi kemana)?"

Nur Iman menjawab, "Kawula bade dakwah kemawon (saya mau berdakwah saja)"

HB I bertanya, "Tindak pundi (pergi kemana)?"

Nur iman menjawab, "Wangsul dumateng Kerisan, (pulang ke dusun Kerisan)."

HB I berkata, "Mboten, Panjenengan kawula paringi tanah, Njenengan mang pilih piyambak (jangan, kakak saya beri tanah, dan kakak pilih tanah mana yang akan ditempati)."

Selanjutnya, Kiai Nur Iman keluar dari Keraton Yogyakarta dan kembali ke dusun Kerisan. Pada waktu itu, di dalam perjalanannya, Kiai Nur Iman melihat sebuah wilayah yang "meleng-meleng tur wangi" (bersinar dan menge- 
luarkan bau harum), maka Kiai Nur Iman memilihnya. Dengan alasan itulah dusun tersebut akhirnya dinamai Mlangi yang berasal dari ungkapan "meleng-meleng tur wangi". Namun demikian, ada juga yang mengatakan Mlangi berasal dari kata "mulangi" yang berarti "mengajar", hal ini merujuk kepada Kiai Nur Iman yang senang mengajar.

Kemudian, Kiai Nur Iman berkata kepada HB I, "kawula remen tanah meniko," (saya senang dengan tanah ini)" dan bertanya "lah, wiyare pinten?" (luasnya berapa).

HB I menjawab, "Wiyare sak kerungune bedug, (luasnya sejauh suara bedug terdengar)", maksudnya adalah apabila bedug ditabuh dan suaranya masih terdengar, maka wilayah tersebut masih menjadi tanah yang diberikan kepada Kiai Nur Iman.

Kiai Nur Iman selanjutnya datang dan menetap di Mlangi. Tanah Mlangi ini disebut sebagai tanah "perdikan", tanah yang dimerdekakan oleh Sultan Yogyakarta yakni tanah yang tidak dikenakan upeti-upeti. Di desa ini, Kiai Nur Iman menetap dan menyiarkan agama Islam kepada Masyarakat hingga akhir hayatnya. Di desa ini dibangun sebuah masjid pathok negara yang menjadi salah satu bukti keterkaitan antara desa ini dengan pihak Keraton Yogyakarta.

\section{Kiai Nur Iman: Keluarga dan Karya-karyanya 2}

Kiai Nur Iman tinggal menetap di dusun Mlangi (sekarang masuk wilayah Desa Nogotirto, Kecamatan Gamping, Kabupaten Sleman, Yogyakarta). Pada awalnya, wilayah Mlangi masih berupa hutan dan persawahan. Kiai Nur Iman membuka daerah ini menjadi sebuah desa dan menyemaikan ajaran-ajaran Islam. Di samping itu, ia juga menjadi penghulu keraton Yogyakarta yang selalu diminta nasehatnya oleh sultan terkait dengan bidang agama. Demikian pula dengan anak cucu keturunan dari kiai Nur Iman; sebagian dari mereka, adalah penghulu dan abdi dalem keraton Ngayogyakarta Hadiningrat.

Tempat tinggal Kiai Nur Iman berada di sebelah barat masjid Mlangi. Setelah meninggal, ia dimakamkan di belakang masjid tersebut. Makam Kiai

${ }^{2}$ Ibid.

Walisongo, Volume 20, Nomor 2, November 2012 
Nur Iman dinamakan Makam Pangeran Bei atau Pesareyan Kagungan Dalem Kasultanan. Hal ini diantaranya ditandai dengan adanya gapura masuk kompleks dan pesareyan atau kuburan yang berciri khas keraton.

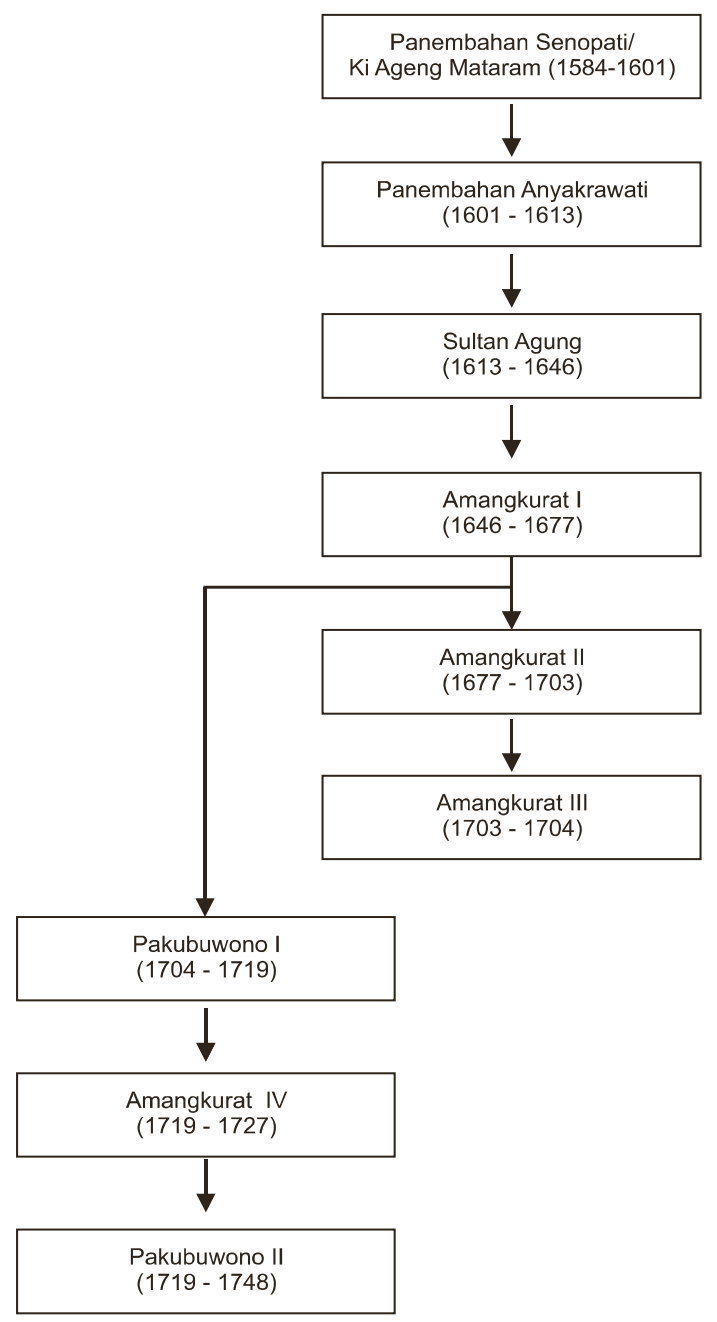

Gambar 1.

Silsilah Raja-raja Mataram 


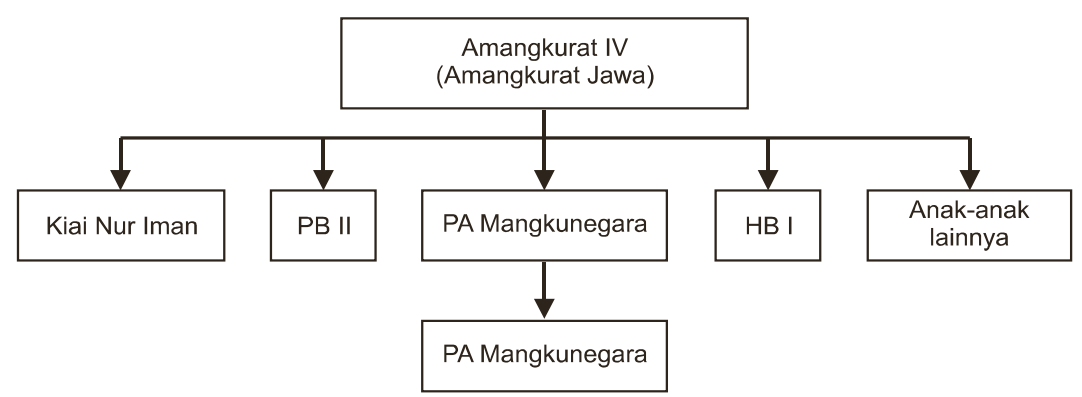

Gambar 2.

Silsilah Kiai Nur Iman

Kiai Nur Iman mempunyai empat istri dan 14 putra dan putri, mereka adalah: (1) Dari istri pertama dari Gegulu bernama Mursalah, mempunyai sembilan orang anak, yaitu Kiai Mursodo, Kiai Nawawi, Nyai Safangatun, R.M Taftoyani, Kiai Mansyur, Nyai Murfakiyah, Kiai Hasan Besari; (2) Dari istri kedua, memiliki tiga orang anak meliputi; Nyai Sholeh, Kiai Salim, Nyai Jaelani; (3) Dari Istri ketiga, mempunyai dua orang putri yakni Nyai Abutohir dan Nyai Mas Tumenggung; (4) Dari istri keempat yakni seorang putri Campa, melahirkan seorang putra bernama RM. Mansyur Muchjidin atau Kiai Guru Loning.

Putra-putri dari Kiai Nur Iman ada yang tinggal menetap di dusun Mlangi, ada pula yang berada di luar Mlangi, misalnya Kiai Mursodo ada di Ploso Kuning dan menjadi penanggung jawab masjid pathok negara di dusun tersebut. Kiai Hasan Besari menjadi penanggung jawab masjid pathok negara di Dongkelan. Anak menantu Kiai Nur Iman yang bernama Kiai Agung Karanglo menjadi penanggung jawab masjid pathok negara di Babadan. Sementara masjid pathok negara di Mlangi diurus oleh Kiai Salim.

Keturunan dari Kiai Nur Iman, sampai saat ini, masih terus meneruskan mengajarkan ajaran-ajaran Islam kepada masyarakat. Di antara mereka ada yang mendirikan pesantren dan ada pula yang menyelenggarakan pengajianpengajian berupa majlis taklim, pengajian di masjid atau rumah-rumah mereka. Berikut ini adalah pesantren yang ada di dusun Mlangi dan dikelola oleh keturunan Kiai Nur Iman: (1) Pesantren Al-Miftah, mulanya diasuh oleh Kiai Siruddin diteruskan oleh K.H. Munahar; (2) Pesantren As-Salafiyyah, 
awalnya diasuh oleh Kiai Masduqi diteruskan oleh K.H. Suja'i Masduqi; (3) Pesantren Al-Falahiyyah, diasuh oleh K.H. Zamrudin dilanjutkan oleh $\mathrm{Ny} . \mathrm{Hj}$. Zamrudin; (4) Pesantren Al-Huda yang diasuh oleh K.H. Muchtar Dawam; (5) Pesantren Mlangi Timur, diasuh oleh K.H. Wafirudin diteruskan oleh $\mathrm{Ny}$. Hj. Wafirudin; (6) Pesantren Hujjatul Islam yang diasuh oleh K.H. Qothrul Aziz; (7) Pesantren As-Salimiyyah, diasuh oleh K.H. Salimi; (8) Pesantren AnNasyath yang diasuh oleh K.H. Sami'an; (9) Pesantren Ar-Risalah yang diasuh oleh K.H. Abdullah; (10) Pesantren Hidayatul Mubtadiin, diasuh oleh K.H. Nur Iman Muqim.

Selain yang telah disebutkan di atas, masih terdapat pesantrenpesantren di luar Mlangi dan atau Yogyakarta yang diasuh oleh keturunan Kiai Nur Iman, mereka antara lain adalah: (1) Pesantren Watu Congol, Muntilan, diasuh oleh K.H. Ahmad Abdul Haq; (2) Pesantren API Tegalrejo, Magelang, diasuh oleh K.H. Abdurrahman Khudlori; (3) Pesantren AlAsy'ariyyah, Kalibeber Wonosobo, diasuh oleh K.H. Muntaha; (4) Pesantren An-Nawawi, Berjan Purworejo, diasuh oleh K.H. Khalwani; (5) Pesantren Bambu Runcing, Parakan Temanggung, diasuh oleh K.H. Muhaiminan; (6) Pesantren Sempu, Secang Magelang, diasuh oleh K.H. Ismail Ali; (7) Pesantren Nurul Iman, Jambi diasuh oleh K.H. Sohib dan Ny. Hj. Bahriyah.

Kiai Nur Iman telah menulis beberapa kitab yaitu kitab al-Sanī alMațālib, Taqwīm, dan al-Risālah. Kitab al-Risālah atau kitab Amtsilah alTașrifiyah merupakan kitab șaraf yang juga terkenal dengan nama kitab fa'ala, disalin oleh Nur Salim bin Abdul Khay Mlangi dan disebarkan oleh Haji Abdullah Muhyiddin. Kitab ini juga dikenal dengan nama Sharaf Mlangi; penjelasan atas kaidah-kaidah ilmu șaraf sedikit berbeda dengan penjelasan yang ada pada kitab șaraf lainnya, misalnya berbeda dengan Sharaf Krapyak. Penjelasan dengan bahasa Jawa yang ada di dalam kitab akan lebih memudahkan santri di dalam mempelajarinya. Nampaknya, kitab ini ditujukan bagi para pembelajar pada tahap awal.

Karya Kiai Nur Iman selanjutnya adalah kitab Taqwīm. Kitab ini merupakan kitab Nahwu yakni kitab yang membahas gramatika bahasa Arab. Kitab ditulis dengan bahasa Arab, demikian pula dengan penjelasannya juga dengan bahasa Arab. Disalin oleh santri pesantren Assilimiyah Mlangi Yogyakarta yakni pesantren yang dirintis oleh generasi keenam dari keturunan Kiai Nur Iman. Melihat isi dan cara pemaparannya kitab Taqwīm sepertinya 
ditujukan bagi para pembelajar yang telah mempunyai dasar pemahaman akan tata bahasa Arab. Adapun karya selanjutnya adalah al-Sanī al-Mațālib. Kitab ini akan dijelaskan pada bagian berikutnya.

\section{Deskripsi Kitab al-Sanī al-Mațālib}

Kitab al-Sanī al-Mațālib adalah kitab karya Kiai Nur Iman. Di dalam kitab tidak disebutkan secara spesifik tahun penulisannya, namun diperkirakan kitab ini ditulis pada akhir abad 18-an dan atau awal abad 19-an dengan merujuk pada masa hidup Kiai Nur Iman. Kemungkinan besar kitab ini ditulis ketika usia Kiai Nur Iman sudah cukup dewasa, yakni ketika tingkat kematangan ilmu seseorang sudah cukup mumpuni.

Bahasa yang digunakan di dalam kitab adalah bahasa Arab dengan aksara Arab tanpa harakat. Kitab yang peneliti dapatkan adalah kitab salinan yang ditulis oleh santri As-Salimiyah Mlangi Yogyakarta. Adapun kitab aslinya belum diketahui keberadaannya. Kitab disalin pada 3 Jumadil Awal $1420 \mathrm{H}$ atau 18 Agustus 1999. salinan kitab dicetak dan di sebarkan secara terbatas di kalangan pesantren Assalimiyah dan beberapa pesantren yang ada di Mlangi. Salinan kitab al-Sanī al-Mațālib berukuran lebar $16 \mathrm{~cm}$ dan panjang $21 \mathrm{~cm}$ dan jumlah halaman 39.

\section{E. Aspek Tasawuf dalam kitab al-Sanī al-Mațālib}

Kitab al-Sanī al-Mațālib mengandung ajaran-ajaran tasawuf, baik tasawuf akhlaqi maupun falsafi. Dalam hal ini, tasawuf akhlaqi maksudnya adalah tasawuf yang membahas ajaran mengenai kesempurnaan dan kesucian jiwa melalui pembentukan sikap meliputi takhalli, tahalli dan tajalli.

Aspek tasawuf dalam kitab diawali dengan penjelasan mengenai hakikat Ketuhanan. Hal ini dimaksudkan untuk mengajak pembaca mengenal terlebih dahulu mengenai Tuhan sebelum beranjak kepada hakikat dirinya. Sebagaimana telah dijelaskan pada sub-bab sebelumnya tentang makna kalam yang merujuk pada kalimat "ashhadu allā illāha illallāh wa ashhadu anna Muhammad rasūlullāh." Maknanya adalah tidak akan diperoleh kalimah kecuali mengetahui lafazh Allah.

Dijelaskan pula tentang zuhud yakni bagaimana manusia semestinya membersihkan hatinya. Kaidah yang digunakan adalah af'âl al-qulüb yang 
mencakup delapan aspek yaitu: iman, taubah, inabah, zuhud, tawakkul, sikap berserah diri, rasa rela, dan ikhlas.

Anjuran untuk meninggalkan hal-hal buruk terdapat pada konsep annida (meniadakan). Keterangannya merujuk pada firman Allah SWT yang artinya, "wahai jiwa yang tenang, kembalilah engkau dengan rela" karena mereka senantiasa melihat Tuhan mereka, mereka tinggalkan sifat-sifat tercela dan mereka hidupkan sifat-sifat yang terpuji."

Di dalam Nahwu terdapat kaidah jar yang disimbolkan dengan kasrah. Di dalam kitab ini jar dimaknai sebagai ketetapan hati dalam beribadah kepada ketaatan perintah dan menjauhi larangan dengan kekuasaan-Nya.

Adapun hal-hal yang dapat menurunkan derajat manusia terangkum di dalam kaidah af'äl al-naqișah. Yang dimaksud naqișah adalah hal-hal yang kurang dari tingkatan seorang manusia yang menjadikan tingkatannya turun menjadi tingkatan binatang. Jumlah hal-hal tersebut ada 15 yaitu berlaku hasud, mengumpat (namīmah), ghïbah, țama', riyā', sum'ah, sombong, berbangga diri, berkumpul dengan orang fasik, berprasangka, memandang perilaku bathil, membuka aib orang, membiasakan berlaku maksiat, kikir, dan berambisi tinggi.

Lima belas sifat tercela ini yang semestinya dibersihkan dari hati manusia untuk dapat mencapai kepada maqām selanjutnya. Upaya pembersihan hati ini yang dikenal dengan istilah takhalli. Sementara delapan aspek di dalam afoāl al-qulüb dapat dikategorikan sebagai usaha pengisian hati dengan hal-hal baik atau disebut dengan sebutan tahalli.

Selain aspek tasawuf akhlāqiy, kitab al-Sanī al-Mațālib memaparkan bagaimana beranjak dari tasawuf akhlāqiy ke tasawuf falsafiy. Konsep tersebut terdapat pada penjelasan mengenai i lafżiyyah dan ma'nawiyyah. Pertama, ị̂afah lafżiyyah adalah hal yang mengharuskan hamba untuk melaksanakan kewajiban syariat dan ibadah badaniyah. Kedua iḍāfah ma'nawiyyah adalah keharusan rūh dan sirr sanubari untuk mencintai Allah SWT dengan meniadakan selain-Nya dari hatinya.

Lebih lanjut dijelaskan, muḍari' yaitu yang menyerupai isim; maksudnya adalah menyerupai isim Allah SWT. Seorang ahli hakikat ilāhiyyah adalah hamba yang mengalami fase-fase perbuatan berikut ini: (1) Keteguhan untuk melepaskan diri dari belenggu nafsu; (2) Shalat yang diibaratkan sebagai keteguhan untuk mendirikan sifat keesaan; (3) Qiyām; kesenantiasaan hamba 
dalam maqām baqā'dengan Tuhan-nya; (4)Ruku': pandangan seorang hamba untuk melihat segala hal berada di bawah wujud ketuhanan;(5) Sujud: kefanaan aspek-aspek manusiawi seorang hamba karena keteguhannya untuk menyatu dengan zat yang tersucikan; (6) Duduk tasyahud; kesempurnaan esensi ilähiyyah (al-haqq) dalam diri seorang hamba yaitu kecenderungannya untuk melihat pada perwujudan Tuhan daripada perwujudan makhluk; (7) Puasa; keteguhan hamba untuk menghindari hal-hal yang tidak penting baginya agar bisa menghayati sifat Sang Mahakekal, (8) Haji; keteguhan hamba untuk meminta kepada Allah SWT; (9) Ihrām; keinginan hamba untuk tidak melihat lagi kepada makhluk; (10) Wuqūf di Arafah; maqām ma'rifat; (11) Tawaf yang menggambarkan pencapaian hamba terhadap hal yang semestinya ia dapatkan; (12) Țawaf tujuh kali; tujuh dari semua sifat Allah SWT yang kepada tujuh sifat tersebut ia berusaha untuk meneladaninya sebagaimana difirmankan dalam hadits qudsi, "Aku menjadi pendengarannya yang dengannya ia mendengar"; (13) Sa'i antara Shafa dan Marwah yang diibaratkan sebagai sa'i (perpindahan) dari sifat-sifat makhluk menuju sifatsifat ilahiyah; (14) Pencukuran rambut (tahallul) yang diibaratkan sebagai pencapaian hamba atas bimbingan ilahiyah. Ketika sifat-sifat ilahiyah telah berhasil dimanifestasikan oleh seorang hamba, maka ia telah mencapai hakikat.

Elemen-elemen di dalam ibadah dimaknai dengan penjelasan tasawuf yang dapat mengantarkan seseorang mencapai taraf hakikat. Hal ini menyiratkan bahwa untuk mencapai tasawuf falsafi dibutuhkan "syariat". Makna dari tasawuf falsafiy; rumusan-rumusan pemikiran tentang kemungkinan manusia mengalami kesatuan dengan Tuhan.

Kitab al-Sanī al-Mațālib menyebutkan beberapa ajaran tentang tasawuf falsafi, diantaranya; Isim ma dan la yang digunakan untuk menegasikan al-jinsi. Isim tersebut adalah tingkatan kesatuan karena Ia tidak dicirikan oleh jenis, isim dan sifat yang tertentu karena Ia senantiasa dalam kesempurnaan-Nya dan infallibilitas-Nya dan dalam kewahdaniyahan-Nya. Kemudian tentang fíl yang fä́il-nya belum diketahui maka fã'il-nya tersirat di dalamnya. Hal ini sebagaimana seorang hamba yang tidak bisa lagi merasakan dirinya sendiri karena mabuknya ia dalam rasa cinta azalinya terhadap Tuhannya, seperti dikatakan oleh seorang yang gila karena cinta, "ketika engkau datang padaku dan aku mencintaimu, maka engkau telah merampas seluruh hidupku."

Kiai Nur Iman dalam kitab al-Sanī al-Mațālib menggambarkan, ketika seseorang telah mencapai alam ketuhanan (lahut), maka secara spontan ia 
akan tahu bahwa ia telah mengerti alam kemahakuasaan (malakut). Tuhan

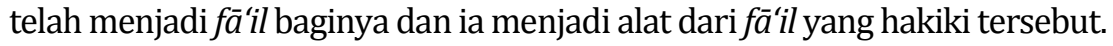

Penjelasan lainnya terdapat pada kaidah mengenai fíil muta'addi, maksudnya adalah fíl yang membuatmu membutuhkan selainmu. Pada saat seorang hamba telah meninggalkan sifat-sifat insaniyahnya dan telah mencapai martabat cinta yang hakiki, ia telah berpindah dari satu maqām ke maqām yang paling tinggi.

Perbuatan manusia terangkum dalam penjelasan mengenai mafūl. Pertama, maf'ūl muțlāq. Kedua, mafūul bih yakni setiap yang dikerjakan manusia dari yang baik atau yang buruk akan ada balasanya. Ketiga, mafūl lah maksudnya adalah apa yang dikerjakan oleh seorang hamba menuntut pahala akhirat dan pahala dunia. Keempat, maf'ül fih; tempat yang diperbolehkan oleh Allah. Kelima, mafül ma'ah; maksudnya adalah sebagaimana yang telah kita lakukan masing-masing, ia berada dalam hakikat, dan ia adalah perbuatan Allah, seolah-olah perbuatan Allah bersama dengan kita.

\section{F. Al-Sanī al-Mațālib: Integrasi dan Interkoneksi antar Disiplin Ilmu}

Kitab al-Sanī al-Mațālib merupakan kitab Nahwu dengan penjelasan makna simboliknya. Membaca kitab ini tidak cukup hanya dipahami dengan kaidah ilmu gramatika bahasa Arab murni, namun perlu juga dengan menyertakan ilmu tasawuf dan ilmu-ilmu lainya. Di dalamnya terdapat interkoneksi antara berbagai cabang ilmu pengetahuan.

Tidak dapat dipungkiri bahwa ilmu Nahwu merupakan landasan ilmu bagi siapa saja yang hendak mempelajari ilmu-ilmu lain dengan referensi bahasa Arab. Ilmu Nahwu juga merupakan gerbang untuk mendalami linguistik bahasa Arab. Kemunculannya telah dimulai sejak Daulah Abbasiyah di Basrah dan Kufah, kemudian berkembang dan terus menyebar ke berbagai wilayah di dunia. Diceritakan, ilmu Nahwu pertama kali dikembangkan oleh Abu al-Aswad al-Du'ali, namun ada pula yang menyebut Abdurrachman ibn Hurmuz. Sementara yang lain mengatakan Ali bin Abi Thalib sebagai peletak dasar ilmu Nahwu dan kemudian dikembangkan oleh Abu Aswad ad-Du'ali. ${ }^{3}$

3 Ridwan, “Karakteristik Nuhat Kufah dan Bashrah," diunduh dari: http:// jurnallingua.com/edisi-2006/5-vol-1-no-1/36-karakteristik-nuhat-kufah-dan-bashrah.html 
Ilmu Nahwu telah mengalami beberapa fase perkembangan yaitu; pertama, masa peletakan dan penyusunan yang berpusat di Basrah. Kedua, masa pertumbuhan berpusat di Basrah dan Kufah. Ketiga, fase penyempurnaan dilakukan oleh ulama-ulama di dua kota Basrah dan Kufah. Keempat, fase penyebaran ke kota-kota lain seperti Baghdad, Mesir, Syria, dan Andalusia, dilakukan oleh para alumni madrasah di Basrah dan Kufah. ${ }^{4}$

Dasar-dasar ilmu Nahwu yang telah diletakkan pada periode awal, selanjutnya dikembangkan oleh ulama-ulama berikutnya, misalnya Isa Ibn Umar al-Tsaqafi menulis dua kitab Nahwu "al-Jamıे" dan "al-Ikmāl". Khalid ibn Ahmad (w. 175 H/791 M) membuat kaidah-kaidah tentang mabni, mushtaq, 'āmil dan ma'mūl, serta menetapkan kaidah samā'i, qiyās dan ta'līl. Selanjutnya, pada pertengahan abad ke-2 Hijriah, ilmu Nahwu mengalami perkembangan pesat dan menyebar ke berbagai wilayah. Pada masa selanjutnya, ulama-ulama tidak lagi membuat kaidah-kaidah baru di bidang ilmu Nahwu, mereka lebih pada memberi sharh (penjelasan). Namun demikian, para ulama tersebut tidah hanya mendalami ilmu Nahwu saja, akan tetapi juga ahli di bidang lainnya seperti fiqih, tasawuf, tafsir, hadits dan lainnya. ${ }^{5}$

Pada periode belakangan, terdapat beberapa ulama yang menulis syarah atas kitab-kitab Nahwu. Imam Qusyairi, seorang ahli sufi, fikih, hadits dan lainnya, menulis sebuah kitab berjudul Nahwu al-Qulūb. Kitab tersebut membahas kaidah-kaidah gramatika bahasa Arab dengan sudut pandang tasawuf. Beberapa bab dari Matan al-Ajurūmiyah juga dibahas di dalam kitab dengan disertai contoh-contoh dan ilustrasi berkaitan dengan aspek spiritualitas manusia yakni hati sebagai poros utama. Aspek sufistik dari Nahwu dikaji dengan detail. Judul dari kitab ini bermakna Nahwu hati, hal ini mencerminkan isi dari kitab. ${ }^{6}$ Ibnu Maimun, seorang ulama dari Maroko, menulis kitab al-Risālah al-Maymuniyyah fi Tawhīd al-Ajurūmiyyah. Kitab ini juga membahas masalah Nahwu dengan perspektif tasawuf.7 Selain itu, Syaikh Abdul Qodir bin Ahmad al-Kuhany menulis kitab berjudul Maniyyat al-Faqir

\footnotetext{
${ }^{4}$ Ibid.

${ }^{5}$ Ibid.

6 Nawawi, Makmun, "Nahwu Hati di Kalangan Ulama Islam; Penguasaan Ilmu Nahwu merupakan Landasan Fundamental yang Tidak Bisa Ditawar-tawar Lagi,” 2011. Diunduh dari; http://bataviase.co.id/node/763229.

${ }^{7}$ Naji, Dairobi. A, Nahwu Sufi; Paradigma Unik Ibnu Maymun di Balik Ajurumiyah, 2004.
} 
al-Munjarid wa Sayrat al-Murid al-Mutajarrid, memaparkan kaidah gramatika bahasa Arab dari kitab Ajurümiyyah dengan makna-makna tasawuf.

Dari pemaparan di atas, dapat diketahui karya Kiai Nur Iman al-Sanī alMațālib bukanlah satu-satunya karya yang mengulas gramatika bahas Arab dengan penjelasan tasawuf. Meskipun demikian, karya dari Kiai Nur Iman tersebut tetap memiliki arti penting dan bermakna. Karya ini lahir dari seorang kiai dengan latar belakang keluarga keraton Kartasura dan Yogyakarta, juga di tengah masyarakat Jawa. Pada masa itu, Keraton Yogyakarta khususnya, dihadapkan pada keadaan sulit dalam menghadapi penjajah Belanda, dan pada saat yang sama Keraton juga musti meningkatkan pamor dihadapan rakyatnya. Oleh karenanya, Keraton membuat proyek kultural dengan membuat serat-serat seperti Serat Suryo Rojo, Serat Menak Malebari dan lainnya. Kegiatan ini dimaksudkan agar masyarakat mengetahui bahwa Keraton Yogyakarta masih memperhatikan dan menganut ajaran Islam. ${ }^{8}$

Masayarakat Jawa, pada masa itu, merupakan masyarakat simbol. Dalam hal ini, simbol berfungsi sebagai mediasi untuk menyampaikan pesan dan menyusun sistem epistemologi serta keyakinan yang dianutnya. Bahkan, simbol juga dapat digunakan untuk mengkritik. Simbol dalam masyarakat Jawa yang digunakan untuk mengkritik rajanya dikenal dengan istilah pasemon. ${ }^{9}$

Isi dan penjelasan dari kitab al-Sanī al-Mațālib juga merupakan simbol. Di dalamnya memuat bagaimana sejatinya seorang manusia dan lainnya. Aspek tasawuf dalam kitab tersebut di awali dengan penjelasan mengenai hakikat Ketuhanan. Nampaknya, hal ini dimaksudkan untuk mengajak pembaca mengenal terlebih dahulu mengenai Tuhan sebelum beranjak kepada hakikat dirinya. Sebagaimana dalam runtutan di dalam pelajaran Islam, Tauhid berada pada tahap awal. Di dalam kitab disebutkan; "Kalām adalah apa yang terdiri dua kata; ashhadu allā illāha illallāh wa ashhadu anna Muhammad rasūlullāh. Tidak akan diperoleh kalimah kecuali mengetahui lafazh Allah, lafal tersebut adalah isim żat". Penjelasan mengenai apa makna kalam ini menyiratkan akan pentingnya posisi shahadat.

8 Tashadi dan Mifedwil, J.(Ed), Kanjeng Kyai Surya Raja; Kitab Pusaka Kraton Ngayogyakarta Hadiningrat, (Yogyakarta: YKII bekerjasama dengan IAIN Sunan Kalijaga, 2002).

${ }^{9}$ Hariwijaya, M., Islam Kejawen, (Yogyakarta: Gelombang Pasang, 2004). 
Kemudian, pemaknaan terhadap kaidah gramatika bahasa Arab menyangkut kepatuhan manusia terhadap Tuhan. Disebutkan; "Jama' mudhakar salim dengan wawu dan ya" maksudnya sesungguhnya laki-laki yang salim (selamat) dari pelanggaran dan patuh pada Tuhan akan sampai kepada maqām kesempurnaan." Disebutkan, "Manusia dibagi menjadi dua macam yakni munșarif yaitu manusia mau menerima peraturan Tuhan, dan ia merupakan makhluk yang ikhlas secara ruh dan ghairu munșarif yaitu manusia yang tidak menerima apa yang sampai secara hakikat, karena di dalamnya ada dua 'illah/sebab dari sembilan 'illah yang ada."

Penjelasan tersebut menyiratkan akan perlunya mengikuti ajaran dan aturan Tuhan atau syariat. Baru kemudian berlanjut kepada penjelasan mengenai tasawuf. Di dalam kitab disebutkan tentang zuhud, juga bagaimana manusia semestinya membersihkan hatinya. Ajaran-ajaran tasawuf tersebut lebih cenderung kepada tasawuf akhlaqi yakni membahas ajaran mengenai kesempurnaan dan kesucian jiwa yang di formulasikan pada pengaturan sikap mental dan pendisiplinan tingkah laku melalui pengosongan diri dari sifat-sifat tercela (takhalli), pengisian dengan sifat-sifat terpuji (tahalli), dan tersingkapnya hati dari tabir dan perolehan nur yang selama ini gaib (tajalli). ${ }^{10}$ Penjelasan selanjutnya dibahas pada sub bab berikut ini.

\section{G. Kesimpulan}

Kitab al-Sanī al-Mațālib karya Kiai Nur Iman ini merupakan kitab yang tidak mudah untuk dipahami. Penjelasan-penjelasan tasawuf dan makna simbol dari aturan dalam ilmu Nahwu tersebut menuntut pembacanya untuk menelaah tidak hanya dari satu perspektif ilmu pengetahuan. Seseorang yang belum pernah membaca kaidah tata bahasa Arab seperti yang tertuang dalam kitab al-Ajurūmiyyah, Imriți, Alfiyah Ibn Malik dan atau kitab Nahwu lainnya, akan mengalami kesulitan di dalam menangkap keterangan yang dikandung di dalam kitab. Pun demikian, diperlukan pula pra-wacana mengenai ilmu tasawuf, karena pemaparan akan makna-makna yang ada dalam kaidah gramatika bahasa Arab tersebut menggunakan kaidah yang ada di dalam ilmu

10 Hadi, Syamsul, dkk., Aspek-Aspek Islam dalam Manuskrip Kraton, (Yogyakarta: YKII bekerjasama dengan IAIN Sunan Kalijaga Yogyakarta, 2006). 
tasawuf. Kitab al-Sanī al-Mațālib ini diperkirakan ditulis pada akhir abad ke18an dan atau awal abad ke-19an.

Adapun penulisnya, Kiai Nur Iman adalah seorang ulama abad $18 \mathrm{M}$. Selain al-Sanī al-Mațālib, ia juga telah menghasilkan karya tulis lain, yaitu kitab Taqwīm dan al-Risālah. Ia adalah seorang ulama dengan darah keraton, ia merupakan putra dari Amangkurat IV/Amangkurat Jawa raja dari kerajaan Mataram. Masa kecil hingga menjelang dewasa ia habiskan di pesantren di Gedangan Surabaya. Di tempat inilah ia belajar ilmu-ilmu agama, sampai akhirnya ia diminta pulang ke keraton Kartasura oleh ayahandanya. Meski kembali ke keraton, ia lebih senang memilih tinggal di luar istana untuk menyiarkan agama Islam. Awalnya ia bertempat tinggal di Gegulu, kemudian Kerisan, dan akhirnya menetap di Mlangi Yogyakarta sampai akhir hayatnya.[w] 


\section{BIBLIOGRAFI}

Abdillah, Zamzan Afandi, "Pengaruh Filsafat terhadap Nahwu; Pro-Kontra Pengaruh Filsafat terhadap Nahwu," Diunduh dari: http://rumahterjemah. com/lainnya/pengaruh-filsafat-terhadap-nahwu/

Abdullah, Amin, Islamic Studies di Perguruan Tinggi, Pendekatan Integrasi Interkonektif, Yogyakarta: Pustaka Pelajar, 2007.

Bruinessen, Martin V, Kitab Kuning Pesantren dan Tarekat: Tradisi Tradisi Islam di Indonesia, Bandung: Mizan, 1995.

Dwiyanto, Djoko, Keraton Yogyakarta; Sejarah, Nasionalisme dan Teladan Perjuangan, Yogyakarta: Paradigma Indonesia, 2006.

Hadi, Syamsul., dkk., Aspek-Aspek Islam dalam Manuskrip Kraton, Yogyakarta: YKII bekerjasama dengan IAIN Sunan Kalijaga Yogyakarta, 2006.

Hariwijaya, M, Islam Kejawen. Yogyakarta: Gelombang Pasang, 2004.

Hidayat, Taufik dan Adib, Ma'wal, Sekilas Sejarah Mbah Kiai Nur Iman (BPH Sandiyo) dan Berdirinya Masjid Jami' Mlangi, Yogyakarta: Pelaksana Penyelenggara Khaul Mbah Kiai Nur Iman Mlangi, 2006.

Jamhuri, Muhammad, "Filsafat Ilmu Nahwu," 2010, http:// jejaknahwushorof. blogspot.com/2010/05/filsafat-ilmu-nahwu.html.

Khuluq, Latiful, Fajar Kebangunan Ulama; Biografi Hasyim Asy'ari, Yogyakarta: LkiS, 2008.

Marlow, C, Research Methods for Generalist Social Work, Toronto: Brooks/Cole, 2001.

Naji, Dairobi. A., Nahwu Sufi; Paradigma Unik Ibnu Maymun di Balik al-Jurumiyah, 2004.

Nawawi, Makmun, "Nahwu Hati di Kalangan Ulama Islam; Penguasaan Ilmu Nahwu merupakan Landasan Fundamental yang Tidak Bisa Ditawar-tawar Lagi," 2011, http://bataviase.co.id/node/763229.

Purwosemantri, R.L, Keraton Ngayogyakarta Hadiningrat; Sujarah sarta Sawatawis Pranatan Lampah Budaya/Adat (Ugi Ngrewat Bab-bab Wigatos Sanesipun), 1944.

Walisongo, Volume 20, Nomor 2, November 2012 
Qodir, Abdul Syaikh bin Ahmad al-Kuhany, Maniyyat al-Faqir al-Munjarid wa Sayrat al-Murid al-Mutajarrid. Diterjemahkan oleh Diya'uddin Luqoni dan Dahril Kamal, Rahasia Ilahi di Balik Gramatika Bahasa Qur'any sebuah Telaah Sufistik ata Kitab al-Jurumy.

Rachman, Budhy Munawar, Ensiklopedi Nurcholis Madjid. Jakarta: Mizan, 2006.

Ridwan, "Karakteristik Nuhat Kufah dan Bashrah," 2006, http://jurnallingua.com /edisi-2006/5-vol-1-no-1/36-karakteristik-nuhat-kufah-dan-bashrah.html.

Santosa, Revianto Budi, Dari Kabanaran menuju Yogyakarta; Sejarah Hari Jadi Kota Yogyakarta, Yogyakarta: Dinas Pariwisata Seni dan Budaya Kota Yogyakarta, 2008.

Suharso dan Retnoningsih, Ana, Kamus Besar Bahasa Indonesia, Semarang: Widya Karya, 2005.

Tatang, dkk. (ed.), Islam dan Khazanah Kebudayaan Kraton Yogyakarta. Yogyakarta: YKII, 1998.

Tashadi dan Mifedwil, J., (ed.), Kanjeng Kiai Surya Raja; Kitab Pusaka Kraton Ngayogyakarta Hadiningrat, Yogyakarta: YKII bekerjasama dengan IAIN Sunan Kalijaga, 2002.

Wiranta, S \& Hadisuwarna, Pengolahan dan Analisis Data Bidang IPS, Modul Diklat Fungsional Peneliti Tingkat Pertama. Pusat Pembinaan, Pendidikan dan Pelatihan Peneliti LIPI, 2007.

Widiyastuti, "Fungsi, Latar Belakang Pendirian, dan Peranan Masjid-masjid Pathok Negara di Kasultanan Yogyakarta," Skripsi, Yogyakarta: Fakultas Sastra UGM Yogyakarta, 1995. 